\title{
Effects of Magnetized Medium on In Vitro Maturation of Porcine Cumulus Cell-Oocyte Complexes
}

\author{
Yun-Jung Kim ${ }^{1}$, Sang-Hee Lee ${ }^{1}$, Soo-Jung Jung ${ }^{2,3}$, and Choon-Keun Park ${ }^{1 *}$ \\ ${ }^{1}$ College of Animal Life Sciences, Kangwon National University, Chuncheon 200-701, Korea \\ ${ }^{2}$ Financial Accounting, Seoul National University, Seoul 151-742, Korea \\ ${ }^{3} J u n g-J i n$ Pig Farm, Heongseong 225-872, Korea
}

(Received 4 March 2014, Received in final form 23 June 2014, Accepted 3 July 2014)

\begin{abstract}
The objective of this study was to study the effect of magnetized water on porcine cumulus cell-oocyte complexes (COCs). Oocytes obtained from female pig were cultured in a medium magnetized at $0,2000,4000$, and 6000 Gauss (G) for 5 minutes using the neodymium magnet. Subsequently, intracellular hydrogen peroxide $\left(\mathrm{H}_{2} \mathrm{O}_{2}\right)$ concentration, glutathione (GSH) activity, oocyte membrane integrity, anti-apoptosis factor Bcl-xL expression, and nuclear maturation were analyzed. The intracellular $\mathrm{H}_{2} \mathrm{O}_{2}$ levels in COCs cultured for 44 hours were not significantly different among the variously magnetized samples. However, GSH activity were significantly higher in the magnetized samples compared to the $0 \mathrm{G}$ sample. The Bcl-xL mRNA expression in COCs cultured for 44 hours was higher in the $4000 \mathrm{G}$ sample than other treatment groups. Membrane damage in COCs cultured for 22 and 44 hours was significantly lower in $4000 \mathrm{G}$ group than control group. On the other hand, nuclear stages as maturation indicator significantly increased in 2000, 4000, and $6000 \mathrm{G}$ groups compared to $0 \mathrm{G}$ group. These results indicate that incubation of porcine oocytes and cumulus cells in magnetized medium improves intracellular GSH levels, membrane integrity and nuclear maturation, and inhibits apoptosis in vitro.
\end{abstract}

Keywords : magnetized water, cumulus cell-oocyte complexes, nuclear maturation, in vitro maturation, pigs

\section{Introduction}

Pig is used by many researches due to its physiological similarities to humans [1]. Especially, its use in reproductive research is very important as a model for in vitro production of embryos [2]. Maturation of mammalian oocytes is a sequence of events starting with the germinal vesicle $(\mathrm{GV})$ stage and ending with the second meiotic division and formation of the second polar body [3]. In addition to undergoing nuclear modifications (nuclear maturation) to develop fertilization capacity, oocytes store substances and undergo morphological alteration (cytoplasmic maturation), which promote and are essential for the early development of the embryo. Since in vitro maturation (IVM) is not as efficient as in vivo maturation, new studies are needed to clarify optimal maturation conditions to maximize maturations rates [2]. In addition, the efficiency of IVM techniques is lower in porcine

(C)The Korean Magnetics Society. All rights reserved.

*Corresponding author: Tel: +82-33-250-8689

Fax: +82-33-259-5575, e-mail: parkck@kangwon.ac.kr species than in other species. Four major problems are generally assumed to be the cause of poor results in porcine oocytes [4]. First, during in vitro oocyte maturation the nuclear maturation process is separated from the cytoplasmic maturation component, therefore decreasing the maturation rate in vitro. Second, the fertilization steps are very complicated in vitro, so fertilization rate is lower than in vivo [5]. Third, despite recent developments in the in vitro maturation of pig oocytes, the production of pig embryos still is inefficient in vitro. Finally, oxidative stress appears to be one of the causes of impaired in vitro embryo development [6].

Reactive oxygen species (ROS) are formed continuously in cells as a consequence of both oxidative biochemical reactions and external factors. It is widely accepted that ROS play both positive and negative roles in vivo. Positive are those related to ROS involvement in energy production, phagocytosis, regulation of cell growth and intercellular signaling, and synthesis of biologically active compounds [7]. While physiological levels of oxygen are necessary for cells to live, the presence of excess ROS, such as superoxide radical $\left(\mathrm{O}_{2}^{-}\right)$, hydroxyl radical $(\cdot \mathrm{OH})$, 
and hydrogen peroxide $\left(\mathrm{H}_{2} \mathrm{O}_{2}\right)$, can also have considerable impact on early embryonic viability, as these compounds have been implied to be involved in nuclear fragmentation and apoptosis, mitochondrial degeneration, developmental block during early cleavage stage and mitotic arrest [810].

Glutathione (GSH) is a major non-protein sulfhydryl compound in mammalian cells and is well known for its important role in protecting the cell from oxidative damage [11]. In addition, the intracellular level of GSH is a critical factor that influences oocyte developmental potential after in vitro fertilization (IVF) or somatic cell nuclear transfer [12-14]. The high concentration of GSH in M-II stage oocytes is an indicator of oocyte maturation and a storage pool of GSH for pre-implantation stages of embryo development [15-17].

Magnetization of water by passing through a magnetic field is a non-chemical alternative to changing the properties of the water. Structurally, magnetized water molecules form smaller clusters that are more easily absorbed into cells [18]. Solubility is also increased due to smaller clusters, as well as $\mathrm{pH}$ changes to slightly alkaline, similar to in vivo values. Finally, due to increased electron donor potential, magnetized water has anti oxidative activity. Therefore, we expected that these characteristics of magnetized water will help the in vitro maturation of immature porcine oocytes. In the present study, we measured intracellular hydrogen peroxide $\left(\mathrm{H}_{2} \mathrm{O}_{2}\right)$ levels and glutathione (GSH) levels, membrane damage of cumulus cell-oocyte complexes (COCs) and expression of an anti-apoptotic gene in porcine COCs incubated in medium magnetized with various magnetic strength.

\section{Materials and Methods}

\subsection{Oocytes collection and in vitro maturation}

Porcine ovaries were obtained from gilts at a local slaughterhouse and transported to the laboratory within 2 $\mathrm{h}$ in physiological saline solution supplemented with $0.9 \%$ $\mathrm{NaCl}$ at $38.5^{\circ} \mathrm{C}$. The cumulus cell-oocyte complexes (COCs) were aspirated from follicles 2 to $6 \mathrm{~mm}$ diameter in ovaries using an 18-gauge needle attached to a $10 \mathrm{~mL}$ disposable syringe. The COCs with evenly granulated cytoplasm and compact cumulus cells were selected using mouth pipette and washed three times with PBS-PVA. Then, the COCs were placed into each well for maturation in modified Medium-199 (tissue culture medium199; TCM-199) supplemented with $10 \%(\mathrm{v} / \mathrm{v})$ porcine follicular fluid $(\mathrm{pFF}), 10 \mathrm{ng} / \mathrm{ml}$ of epidermal growth factor (EGF), $10 \mathrm{IU} / \mathrm{ml}$ of human chorionic gonadotropin $(\mathrm{hCG}), 10 \%(\mathrm{v} / \mathrm{v})$ luteinzing hormone $(\mathrm{LH})$ and follicle stimulating hormone (FSH) for $22 \mathrm{~h}$ as the first step of IVM. After $22 \mathrm{~h}$ of maturation culture, the COCs were subsequently cultured in the same maturation medium without hormones for $22 \mathrm{~h}$ as the second step of IVM [19]. The COCs were cultured at $38.5^{\circ} \mathrm{C}$ in an atmosphere of $5 \% \mathrm{CO}_{2} / 95 \%$ air with high humidity.

\subsection{Preparation of magnetized water}

TCM-199 medium for in vitro maturation was circulated through magnetic fields with different gauss $(0,2000$, 4000 , and 6000 gauss; G) using neodymium magnet for 5 $\mathrm{min}$ each. Before the in vitro maturation experiment, each treated medium was kept for $3 \mathrm{~h}$ for equilibration with the gas phase and temperature in four-well multi-dish.

\subsection{Measurement of intracellular ROS and GSH lev-} els in oocytes

The intracellular ROS and GSH levels in oocytes cultured with different magnetic intensity were measured. For the ROS assay, maturated COCs were transferred into four-well multi-dish with culture medium containing 1.5 $\mu \mathrm{M}$ Carboxy-DCFDA (Invitrogen) and $45 \mathrm{nM}$ Hoechst 33342 (Sigma), and then were incubated for $30 \mathrm{~min}$ at $38.5^{\circ} \mathrm{C}$ in the dark. Stained COCs were washed three times in culture medium. The COCs were determined using the CellTracker ${ }^{\mathrm{TM}}$ Red CMTPX (Invitrogen) for the GSH assay. The COCs were incubated in medium supplemented with $5 \mathrm{nM}$ GSH staining solution and $225 \mathrm{nM}$ Hoechst 33342 (Sigma), and washed in serum-free TC199 medium. The experiments were replicated three times with a group of 30 COCs in each treatment group. After the GSH assay, the COCs were transferred to 96 well plate (black) for fluorescence intensity measurement with Microplate Spectrofluormeter (Molecular Device) and pictures were taken under the Confocal Laser Microscope (Olympus).

\subsection{Evaluation of cumulus cell membrane damage}

The integrity of oocyte membrane was estimated by staining with LIVE/DEAD Kit (Molecular Probes). Briefly, the oocytes cultured with magnetized water for different time periods were added $3.5 \mu \mathrm{L}$ of SYBR-14 and propidium iodide (PI) from a working solution containing 100 $\mathrm{nM}$ SYBR-14 and $12 \mu \mathrm{M}$ PI. They were incubated at $38.5^{\circ} \mathrm{C}$ for $15 \mathrm{~min}$, and then washed three times in PBSPVA solution. Stained oocytes were transferred into 96 well plate (black) before analysis and observed under the Microplate Spectrofluormeter (Molecular Device).

\subsection{Quantitative reverse transcription PCR analysis}

To confirm anti-apoptotic gene expression in COCs 
Table 1. Primer sequences used in RT-PCR analysis.

\begin{tabular}{ccc}
\hline \hline Gene & Primer sequence & $\begin{array}{c}\text { Product size } \\
(\mathrm{bp})\end{array}$ \\
\hline \multirow{2}{*}{ Bcl-xL } & $\begin{array}{c}\text { F: 5'-CCCCAGGGACAGCGTATCAG-3' } \\
\text { R: 5'-AGAGCGAACCCAGCAGAACC-3' }\end{array}$ & 345 \\
\hline \multirow{2}{*}{ GAPDH } & F: 5'-TCGGAGTGAACGGATTTG-3' & 200 \\
& R: 5'-CCTGGAAGATGGTGATGG-3' & \\
\hline
\end{tabular}

Table 2. The PCR conditions.

\begin{tabular}{ccccc}
\hline \hline \multirow{2}{*}{ Gene } & \multicolumn{2}{c}{ Temperature $\left({ }^{\circ} \mathrm{C}\right) /$ Time $(\mathrm{sec})$} & \multirow{2}{*}{ Cycles } \\
\cline { 2 - 4 } & Denaturation & Annealing & Extension & \\
\hline Bcl-xL & $94 / 30$ & $56 / 30$ & $72 / 30$ & \multirow{2}{*}{45} \\
GAPDH & $94 / 30$ & $59 / 30$ & $72 / 30$ & \\
\hline
\end{tabular}

cultured with magnetized medium for $44 \mathrm{~h}$, the total messenger RNA (mRNA) was extracted using Trizol reagent (TaKaRa) and Chloroform (J. T. BAKER) after centrifugation at $12,000 \mathrm{rpm}$ for $15 \mathrm{~min}$ of 150 oocytes per each group. Isolated mRNA was measured with NanoDrop (Thermo Scientific). Calculated total RNA were mixed with reverse transcription (RT) premix kit (Intron biotechnology) for cDNA synthesis. The RT was processed with a program of $45^{\circ} \mathrm{C}$ for $60 \mathrm{~min}$ and $95^{\circ} \mathrm{C}$ for $5 \mathrm{~min}$. After RT, $10 \%$ of the reaction mixture and specific primer for Bcl-xL and GAPDH were used to conduct polymerase chain reaction (PCR, Table 2), and the housekeeping GAPDH gene was used as an internal standard. Subsequent PCR analysis was performed with $95^{\circ} \mathrm{C}$ for $5 \mathrm{~min}, 94^{\circ} \mathrm{C}$ for $30 \mathrm{sec}$, and $56^{\circ} \mathrm{C}$ for $30 \mathrm{sec}$ for $\mathrm{Bcl}-\mathrm{xL}$; for GAPDH at $59^{\circ} \mathrm{C}$ for $30 \mathrm{sec}$, at $72^{\circ} \mathrm{C}$ for 30 sec, followed by a final extension step at $72^{\circ} \mathrm{C}$ for $5 \mathrm{~min}$. These primers produced specific 345 and 200 base pair (bp) chains (Table 1). After PCR, the products were analyzed with electrophoresis with $2 \%$ agarose gels stained with $0.5 \mu \mathrm{g} / \mathrm{ml}$ ethidium bromide $(\mathrm{EtBr})$, visualized with UV light and photographed. Expression of Bcl-xL mRNA was analyzed by a computer system, and relative amount of Bcl-xL mRNA was calculated by normalization with the amount of GAPDH mRNA.

\subsection{Assessment of oocytes nuclear maturation}

To evaluate nuclear maturation of cultured oocytes at $44 \mathrm{~h}$, the COCs were denuded by gently pipetting in IVM medium containing $0.1 \%(\mathrm{w} / \mathrm{v})$ hyaluronidase and washed three times in PBS-PVA. The cumulus-free oocytes were mounted on cleaned glass slides and fixed in 3:1 ethanol : acetic acid solution for 2 days before evaluation [20]. Then the oocytes were stained with $1 \%$ orcein (Sigma) for $15 \mathrm{~min}$ at room temperature and washed three times in aceto-glycerol solution. Stained oocytes were assessed under phase-contrast microscope (Olympus, BX40) and nuclear stages were classified as germinal vesicle $(\mathrm{GV})$, metaphase-I (M-I), metaphase-II (M-II), and degenerated oocytes [21].

\subsection{Statistical Analysis}

Statistical analysis was performed with analysis of variance (ANOVA) using SAS (version 9.1, SAS Institute Inc., Cary, NC, USA). Data are presented as mean \pm standard error of the mean (SEM). Differences in the mean values of sperm damage after treatment with various treatment conditions were processed using Duncan's multiple range tests. Differences were considered significant when $p<0.05$.

\section{Results}

The intracellular $\mathrm{H}_{2} \mathrm{O}_{2}$ levels in oocytes cultured in

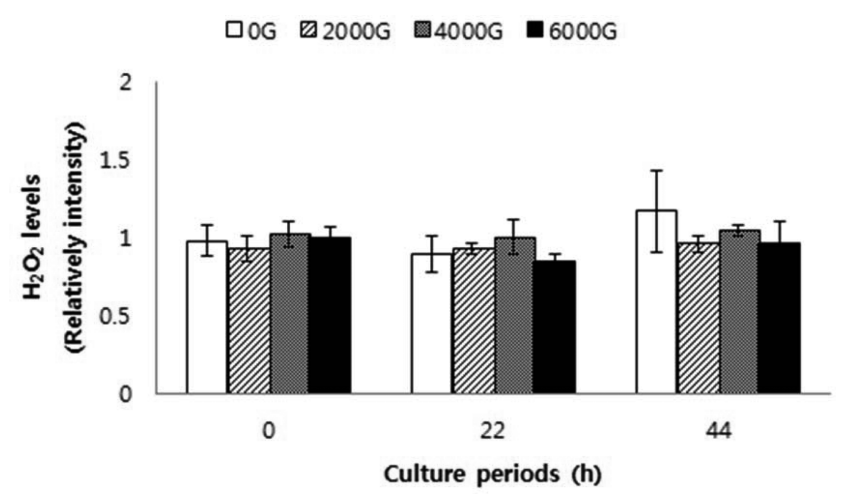

Fig. 1. Changes of $\mathrm{H}_{2} \mathrm{O}_{2}$ levels in porcine cumulus cell-oocyte complexes cultured in magnetized medium for various time periods.

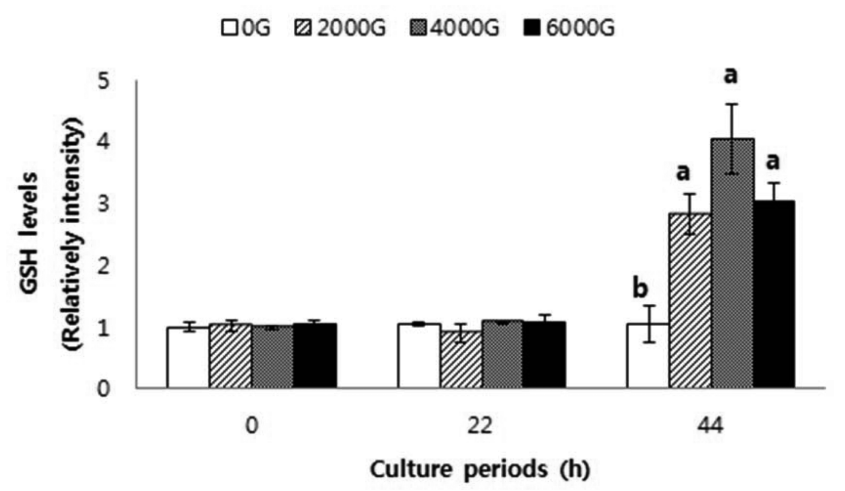

Fig. 2. Changes of GSH levels in porcine cumulus cell-oocyte complexes cultured in magnetized medium for various time periods. Within end point, bars with different letters $(a, b)$ are significantly $(p<0.05)$ different for different intensity of neodymium magnet treatment. 


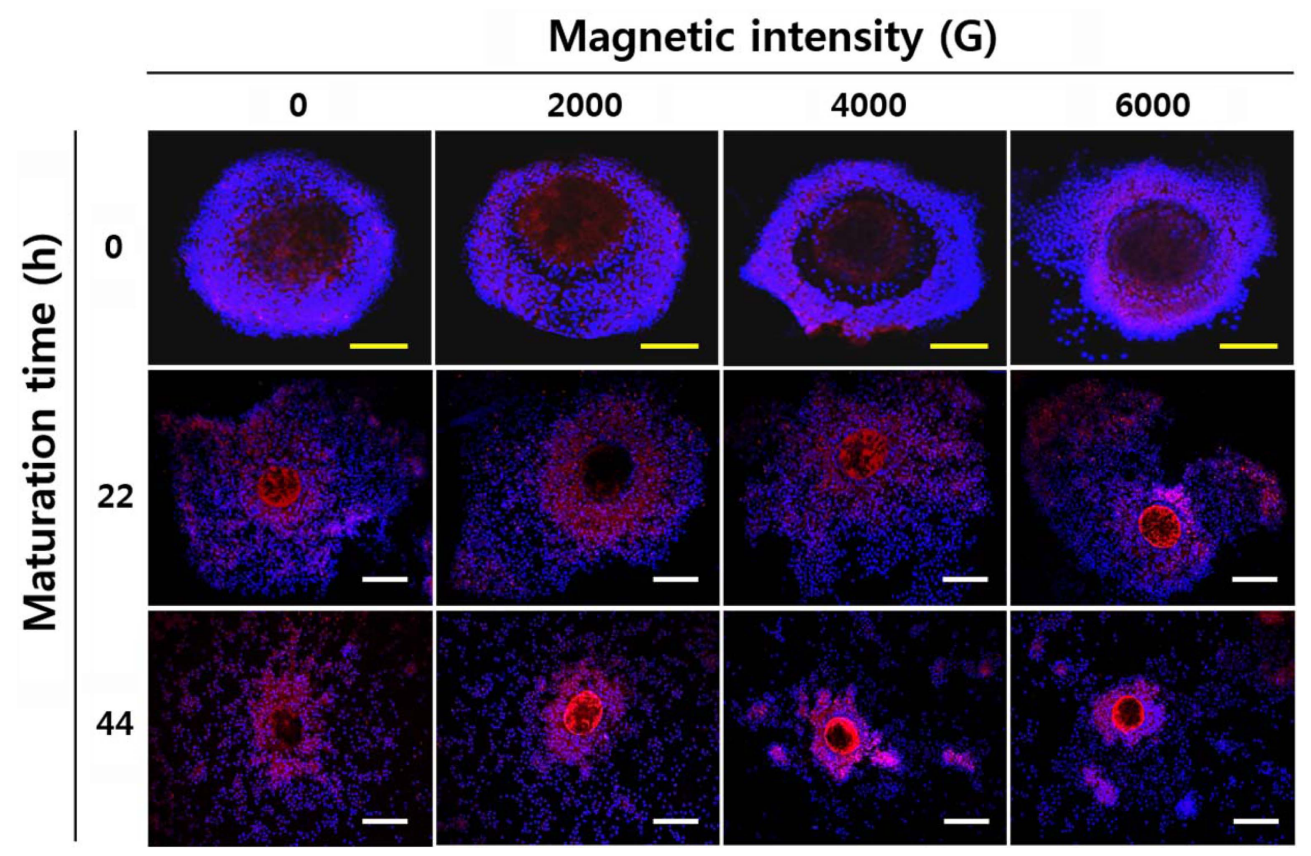

Fig. 3. (Color online) Confocal laser scanning microscopic images of glutathione (GSH) levels during in vitro maturation of porcine cumulus cell-oocyte complexes. Red color spot was meant intracellular GSH level by CellTracker ${ }^{\text {TM }}$ Red CMTPX staining and blue color spot was meant nuclear by Hoechst 33342, and purple color spot was showed CellTracker ${ }^{\mathrm{TM}}$ Red CMTPX and Hoechst 33342 doubling staining. Yellow scale bar was $50 \mu \mathrm{m}$ and white scale bar was $100 \mu \mathrm{m}$.

magnetized medium are shown in Fig. 1. The fluorescence signal of oocytes incubated in differently magnetized medium did not differ significantly at any time during incubation.

Intracellular GSH levels in oocytes cultured in magnetized medium are shown in Figs. 2 and 3. Between 0 and 22 hours of maturation, the intracellular GSH levels were not significantly different among the groups treated with different magnetic strength. However, at 44 hours, the GSH levels were significantly higher in oocytes incubated in magnetized medium $(2000 \mathrm{G}, 2.82 \pm 0.33$; $4000 \mathrm{G}, 4.04 \pm 0.56$; and $6000 \mathrm{G}, 3.04 \pm 0.27$, respectively) compared to oocytes incubated in regular water $(0 \mathrm{G}$, $1.04 \pm 0.30)(p<0.05)$.

Fig. 4 shows levels of $\mathrm{H}_{2} \mathrm{O}_{2}$ and $\mathrm{GSH}$ after the in vitro maturation of oocytes for 44 hours in media magnetized with different magnetic strength. There was no significant difference in $\mathrm{H}_{2} \mathrm{O}_{2}$ levels between the differ-
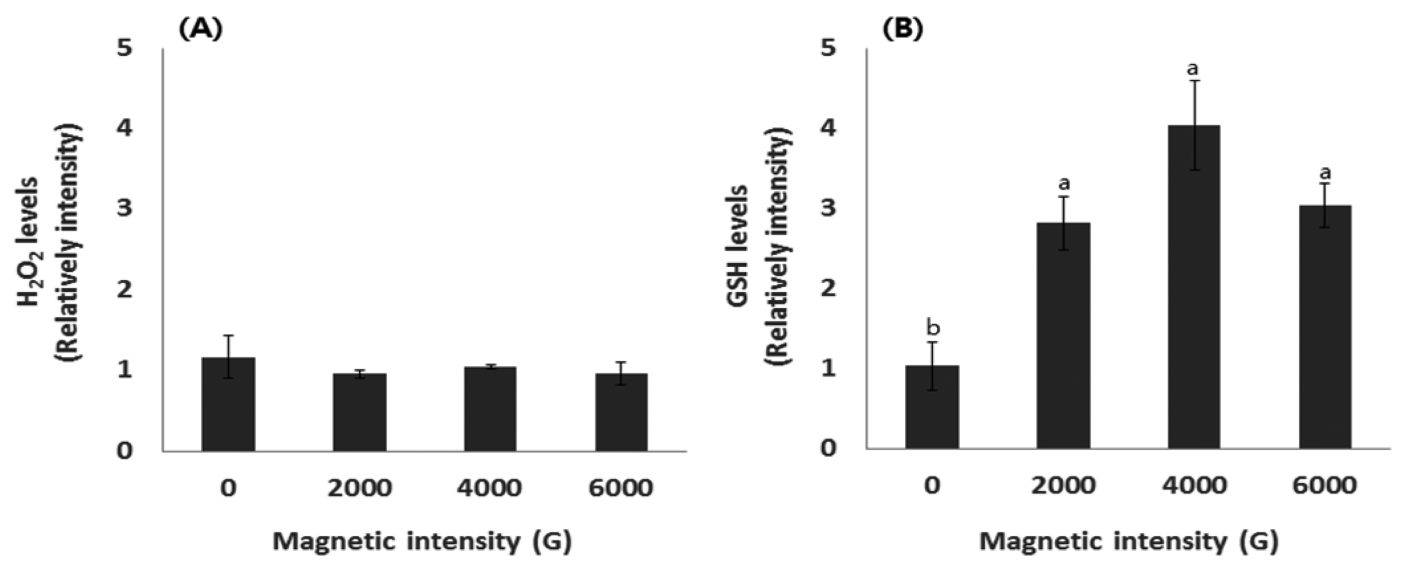

Fig. 4. Changes of $\mathrm{H}_{2} \mathrm{O}_{2}$ (A) and $\mathrm{GSH}$ (B) levels in porcine cumulus cell-oocyte complexes after 44 hours of culture in media magnetized with different magnetic intensity. Within end point, bars with different letters $(\mathrm{a}, \mathrm{b})$ are significantly $(p<0.05)$ different for different intensity of neodymium magnet treatment. 


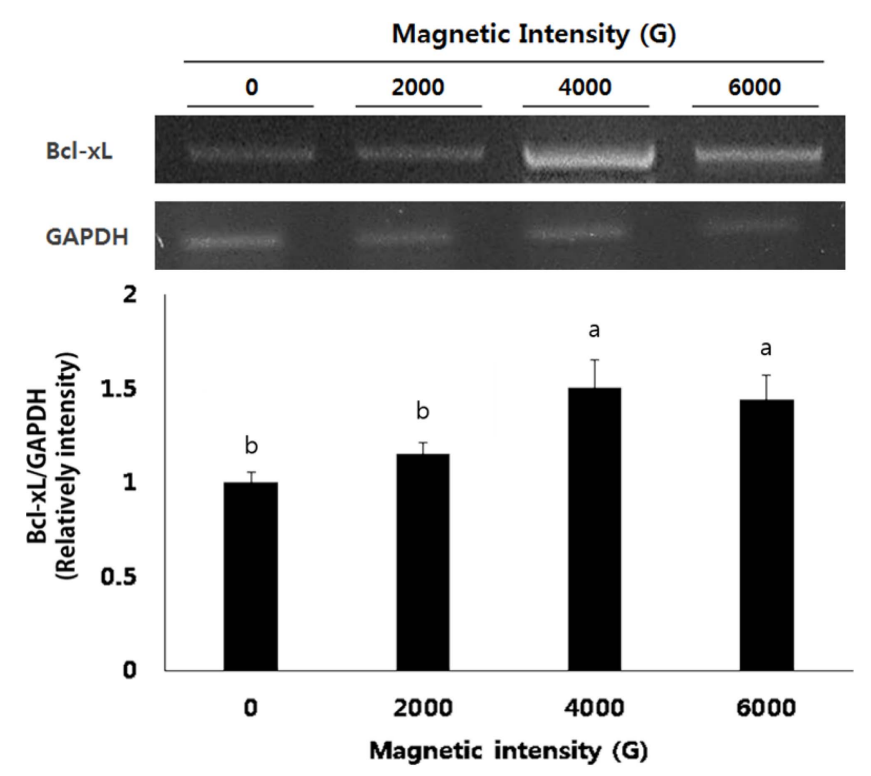

Fig. 5. Expression of Bcl-xL mRNA at 44 hours of in vitro maturation in porcine oocytes. This data was obtained from duplicate experiments per sample, and 100 oocytes per treatment group were used. Within end point, bars with different letters $(\mathrm{a}, \mathrm{b})$ are significantly $(p<0.05)$ different for different intensity of neodymium magnet treatment.

ently magnetized groups. However, GSH levels were significantly higher in groups magnetized with 2000,
Table 3. Cumulus cell membrane damage in porcine oocytes cultured for different time periods in magnetized medium.

\begin{tabular}{cccc}
\hline \hline \multirow{2}{*}{$\begin{array}{c}\text { Magnetic } \\
\text { intensity (G) }\end{array}$} & \multicolumn{3}{c}{ Culture periods of oocytes (h) } \\
\cline { 2 - 4 } & 0 & 22 & 44 \\
\hline 0 & $22.058 \pm 0.383$ & $25.592 \pm 0.494^{\mathrm{ab}}$ & $21.577 \pm 1.098^{\mathrm{ab}}$ \\
2000 & $22.397 \pm 1.605$ & $27.646 \pm 1.859^{\mathrm{a}}$ & $23.863 \pm 1.177^{\mathrm{a}}$ \\
4000 & $22.335 \pm 0.397$ & $21.972 \pm 0.377^{\mathrm{c}}$ & $19.444 \pm 0.873^{\mathrm{b}}$ \\
6000 & $22.482 \pm 0.628$ & $23.148 \pm 0.301^{\mathrm{bc}}$ & $21.152 \pm 1.917^{\mathrm{ab}}$ \\
\hline
\end{tabular}

${ }^{\mathrm{a}, \mathrm{b}}$ Values in the same column with different superscripts are significantly different $(p<0.05)$.

4000 and $6000 \mathrm{G}$ compared to control group (0 G) $(p<$ $0.05)$.

Expression of Bcl-xL mRNA in the porcine oocytes after in vitro maturation in differently magnetized media is shown in Fig. 5. The RT-PCR was performed with GAPDH housekeeping gene as an internal standard. Expression of Bcl-xL mRNA was increased in oocytes incubated in media treated with higher magnetic intensity.

Cumulus cell membrane damage in porcine oocytes cultured in media treated with various magnetic intensity are shown in Table 3. There was no significant difference among all the groups at 0 hours of culture. However, when oocytes were cultured for 22 and $44 \mathrm{~h}$, cumulus cell membrane damage was significantly lower in oocytes

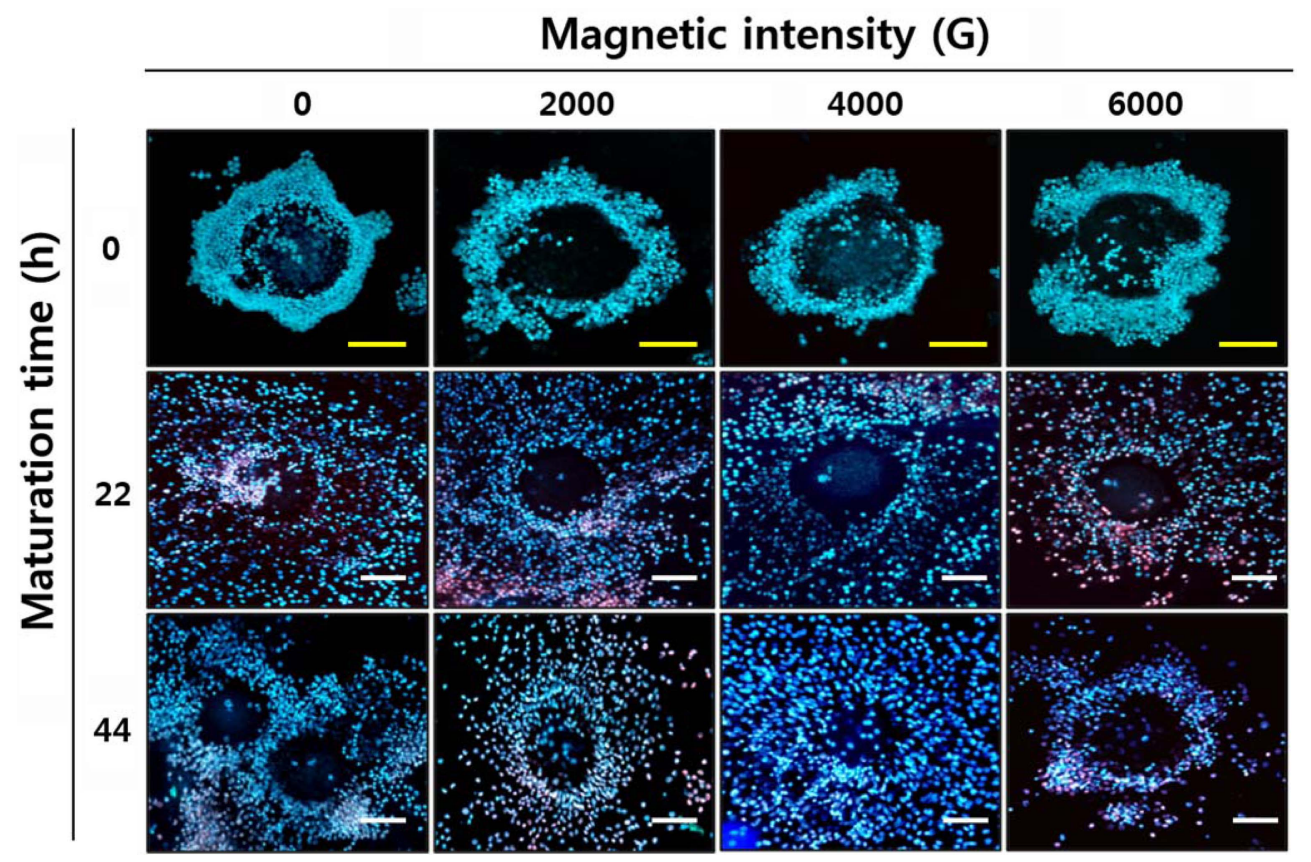

Fig. 6. (Color online) Fluorescent photomicrographic images of cumulus cell membrane damage during in vitro maturation of porcine cumulus cell-oocyte complexes incubated in media magnetized with different magnetic intensity. Green color spot was meant intact plasma membrane cumulus cells by SYBR14 staining and red damaged plasma membrane cumulus cells by propidium iodide (PI) staining. Yellow scale bar was $50 \mu \mathrm{m}$ and white scale bar was $100 \mu \mathrm{m}$. 
Table 4. Changes of oocyte nuclear stages during in vitro maturation of porcine oocytes in magnetized medium.

\begin{tabular}{|c|c|c|c|c|c|}
\hline \multirow{2}{*}{$\begin{array}{c}\text { Magnetic } \\
\text { intensity }(G)\end{array}$} & \multirow{2}{*}{$\begin{array}{c}\text { No. of oocytes } \\
\text { examined }\end{array}$} & \multicolumn{4}{|c|}{ No. (\%) of oocytes matured to } \\
\hline & & GV & M I & M II & Deg \\
\hline 0 & 153 & $\begin{array}{c}15^{\mathrm{a}} \\
(9.64 \pm 1.91)\end{array}$ & $\begin{array}{c}51^{\mathrm{a}} \\
(33.25 \pm 3.89)\end{array}$ & $\begin{array}{c}74^{\mathrm{b}} \\
(48.47 \pm 4.91)\end{array}$ & $\begin{array}{c}13^{\mathrm{a}} \\
(8.65 \pm 1.88)\end{array}$ \\
\hline 2000 & 137 & $\begin{array}{c}6^{\mathrm{ab}} \\
(4.40 \pm 0.69)\end{array}$ & $\begin{array}{c}27^{\mathrm{b}} \\
(19.58 \pm 3.93)\end{array}$ & $\begin{array}{c}91^{\mathrm{a}} \\
(66.18 \pm 3.92)\end{array}$ & $\begin{array}{c}13^{\mathrm{a}} \\
(9.84 \pm 1.64)\end{array}$ \\
\hline 4000 & 248 & $\begin{array}{c}4^{\mathrm{b}} \\
(1.36 \pm 0.84)\end{array}$ & $\begin{array}{c}36^{\mathrm{b}} \\
(14.45 \pm 0.75)\end{array}$ & $\begin{array}{c}186^{\mathrm{a}} \\
(75.41 \pm 2.32)\end{array}$ & $\begin{array}{c}22^{\mathrm{a}} \\
(8.78 \pm 1.70)\end{array}$ \\
\hline 6000 & 138 & $\begin{array}{c}7^{\mathrm{ab}} \\
(4.94 \pm 2.73)\end{array}$ & $\begin{array}{c}33^{\mathrm{b}} \\
(23.79 \pm 2.24)\end{array}$ & $\begin{array}{c}93^{\mathrm{a}} \\
(67.62 \pm 4.34)\end{array}$ & $\begin{array}{c}5^{\mathrm{b}} \\
(3.65 \pm 0.56)\end{array}$ \\
\hline
\end{tabular}

${ }_{\mathrm{a}, \mathrm{b}}$ Values in the same column with different superscripts are significantly different $(p<0.05)$. GV: germinal vesicle, M-I: metaphase-I, M-II: metaphase-II, Deg: degeneration.

incubated in medium magnetized with $4000 \mathrm{G}$ compared to $2000 \mathrm{G}(p<0.05)$.

The effects of magnetized medium on in vitro maturation of porcine oocytes are shown in Table 4. When oocytes were cultured in medium magnetized with various magnetic intensity, the number of nuclear stages was significantly higher at 2000,4000 , and $6000 \mathrm{G}$ compared to control. The highest proportion of oocytes cultured to M-II stage was obtained in the medium magnetized with $4000 \mathrm{G}$.

\section{Discussion}

In this study, we investigated the effects of magnetized water on hydrogen peroxide and glutathione levels in the intracellular space, plasma membrane intactness, gene expression of anti-apoptotic factor and nuclear stages of porcine oocytes.

Reactive oxygen species (ROS) are generated during various cellular metabolic reactions as well as indirectly in the cell's environment [22]. In excess concentrations they cause damage to nucleic acids, proteins, and lipids, and to other cellular components [23, 24]. However, magnetic field inhibits $\mathrm{H}_{2} \mathrm{O}_{2}$ production in cellular systems through changes in the characteristics of cell membrane, effects the cell reproduction and causes certain changes in cell metabolism [23, 25]. Contrary to expectations based on previous studies, which showed that magnetized water inhibits ROS, particularly $\mathrm{H}_{2} \mathrm{O}_{2}$ in the intracellular space, it did not have an effect on $\mathrm{H}_{2} \mathrm{O}_{2}$ levels in porcine oocytes [26]. Moreover, magnetized water is characteristic for the balance between free radical production and their clearance controlled by antioxidant compounds [27]. GSH is the major non-protein sulfhydryl antioxidant in mammalian cells and plays a role in many cellular functions, includ- ing DNA and protein synthesis, regulation of enzyme activity, both inter- and intracellular transport, and is an electron donor for glutathione peroxidase, which reduces peroxide, thereby protecting the cell from oxidative stress and toxic ROS activity [28-30]. In addition, GSH has a unique function in reproduction and is specifically related to oocyte maturation [17]. As reported previously, GSH concentrations are significantly higher in ovulated MII oocytes than in immature GV stage oocytes [31]. However, it was unclear how magnetized water increases intracellular GSH concentration during oocyte maturation in vitro. This study extends the previous observations by showing that GSH concentrations increased significantly at 44 hours of in vitro maturation compared to 0 and 22 hours. Moreover, GSH is a key regulator in apoptosis, since cells actively extrude intracellular GSH through specific carriers and a consequent redox disequilibrium triggers the activation of Bax and cytochrome c release [32]. Previous research shows that magnetized water and high levels of GSH reduced apoptosis by interfering with the apoptotic process [33].

Cumulus cells have a close connection with oocytes during the course of maturation in mammals [34, 35]. It is generally accepted that cumulus cells support the maturation of oocytes to the MII stage and greatly enhance cytoplasmic maturation, which is responsible for the capacity to undergo normal fertilization and subsequent embryonic development [11]. Although cumulus cell is very sensitive to apoptosis, the membrane is modified by magnetized water having the anti-apoptotic ability. Therefore, oocyte nuclear maturation also reached MII phase earlier.

This study shows that magnetized medium with increase in GSH levels improves the in vitro nuclear maturation in porcine oocytes. 


\section{Acknowledgements}

This research was supported by Bio-industry Technology Development Program (IPET 109007-3), Ministry for Food, Agriculture, Forestry and Fisheries, Republic of Korea.

\section{References}

[1] T. Nagai, Theriogenology 55, 1291 (2001).

[2] M. G. Marques, C. Nicacio, V. P. de Oliveira, A. B. Nascimento, H. V. Caetano, C. M. Mendes, M. R. Mello, M. P. Milazzotto, M. E. Assumpcao, and J. A. Visintin, Anim. Reprod. Sci. 97, 375 (2001).

[3] M. R. Blano, S. Demyda, M. M. Mereno, and E. Genero,Biotech. Mol. Biol. Review 6, 155 (2001).

[4] P. Wongsrikeao, Y. Kaneshige, R. Ooki, M. Taniguchi, B. Agung, M. Nii, and T. Otoi, Reprod. Domest. Anim. 40, 166 (2005).

[5] L. R. Abeydeera and B. N. Day, Biol. Reprod. 57, 729 (1997).

[6] C. Matas, P. Coy, R. Romar, M. Marco, J. Gadea, and S. Ruiz, Reproduction 125, 133 (2003).

[7] A. M. G. Mantovani, C. Madeddu, E. L. Mura, E. Massa, G. Gramignano, M. R. Lusso, V. Murgia, P. Camboni, and L. Ferreli, J. Cell Mol. Med. 6, 570 (2002).

[8] P. J. Booth, P. Holm, and H. Callesen, Theriogenology. 63, 2040 (2005).

[9] P. Guerin, S. El Mouatassim, and Y. Menezo, Hum. Reprod. Update. 7, 175 (2001).

[10] H. Tamura, A. Takasaki, T. Taketani, M. Tanabe, F. Kizuka, L. Lee, I. Tamura, R. Maekawa, H. Aasada, Y. Yamagata, and N. Sugino, J. Ovarian Res. 5, 5 (2012).

[11] N. S. Hideki Tatemoto, and M. Norio. Biol. Reprod. 63, 805 (2000).

[12] L. R. Abeydeera, W. H. Wang, T. C. Cantley, R. S. Prather, and B. N. Day, Theriogenology 50, 747 (1998).

[13] D. G. de Matos and C. C. Furnus, Theriogenology 53, 761 (2000).

[14] J. Y. You, J. Y. Kim, J. M. Lim, and E. S. Lee, Theriogenology 74, 777 (2010).

[15] C. C. Furnus, D. G. de Matos, and D. F. Moses, Mol. Reprod. Dev. 51, 76 (1998).
[16] C. S. Gardiner and D. J. Reed, Biol. Reprod. 51, 1307 (1994).

[17] K. A. Zuelke, S. C. Jeffay, R. M. Zucker, and S. D. Perreault. Mol. Reprod. Dev. 64, 106 (2003).

[18] S. Mufarrei, H. A. Batshan, M. I. Shalaby, and T. M. Shafey, Poult. Sci. 4, 96 (2005).

[19] N. Viet Linh, T. Q. Dang-Nguyen, B. X. Nguyen, N. Manabe, and T. Nagai, J. Reprod. Dev. 55, 594 (2009).

[20] J. Zhu, E. E. Telfer, J. Fletcher, A. Springbett, J. R. Dobrinsky, P. A. De Sousa, and I. Wilmut, Biol. Reprod. 66, 635 (2002).

[21] W. Sha, B. Z. Xu, M. Li, D. Liu, H. L. Feng, and Q. Y. Sun, Fertil. Steril. 93, 1650 (2010).

[22] C. M. Combelles, S. Gupta, and A. Agarwal, Reprod. Biomed. Online. 18, 864 (2009).

[23] S. Landolfo, H. Politi, D. Angelozzi, and I. Mannazzu, Biochim. Biophys. Acta 1780, 892 (2008).

[24] C. F. Martino and P. R. Castello, PLoS One 6, e22753 (2011)

[25] M. Hozayn and A. M. S. A. Qados, Agric. Biol. J. North Am. 1, 677 (2010).

[26] F. Carlos and P. R. C. Martion, PILoS ONE 6, e22753 (2011).

[27] A. H. Hashish, M. A. El-Missiry, H. I. Abdelkader, and R. H. Abou-Saleh, Ecotoxicol. Environ. Saf. 71, 895 (2008).

[28] D. Biswas and S. H. Hyun, Theriogenology 76, 153 (2011).

[29] J. Fujii, Y. Iuchi, and F. Okada, Reprod. Biol. Endocrinol. 3, 43 (2005).

[30] S. Luperchio, S. Tamir, and S. R. Tannenbaum, Free Radical Biol. Med. 21, 513 (1996).

[31] S. D. Perreault, R. R. Barbee, and V. L. Slott, Dev. Biol. 125, 181 (1988).

[32] M. de Nicola, S. Cordisco, C. Cerella, M. C. Albertini, M. D'Alessio, A. Accorsi, A. Bergamaschi, A. Magrini, and L. Ghibelli, Ann. N. Y. Acad. Sci. 1090, 59 (2006).

[33] C. Fanelli, S. Coppola, R. Barone, C. Colussi, G. Gualandi, P. Volpe, and L. Ghibelli, FASEB J. 13, 95 (1999).

[34] J. J. Eppig. Dev. Biol. 89, 268 (1982).

[35] N. B. Gilula, M. L. Epstein, and W. H. Beers, J. Cell Biol. 78, 58 (1978). 